\title{
From Idealised Moral Community to Real Tiger Society. The Catholic Church in Secular Ireland
}

\author{
Jean-Christophe Penet \\ National Centre for Franco-Irish Studies, ITT
}

Copyright (c) 2008 by Jean-Christophe Penet. This text may be archived and redistributed both in electronic form and in hard copy, provided that the author and journal are properly cited and no fee is charged for access.

\begin{abstract}
From the 1960s to the 1980s, a time of "tension management" between "the old hegemony of Catholicism and nationalism and the emergence of liberalism and materialism" (Fogarty 1984: 102), Ireland's self-image as a moral community came under the influence of secularisation. The country's secularisation process speeded up when it decided to embrace new technologies - and consequently met with huge economic success - in the early 1990s, the results of which for Catholicism in Ireland were the visible and apparently irreversible undermining of the institution. My argument in this article is that, whereas in an Ireland which many viewed as a traditional, wellintegrated religious nation, it was possible for Irish Catholics to live their faith in an institutionalised manner through the idealised moral community desirable both to Church and State, economic success and increased internationalisation made this idea of community less sustainable. Indeed, in what has now become a "network society" (Castells 1996: 469), there has emerged a new breed of Catholics who no longer live their religion as a transcendent inheritance but as an immanent choice, and who, therefore, seem to "connect" to their religion more than they "commune" with it.
\end{abstract}

Key Words: Irish Catholicism, moral community, secularisation, Celtic Tiger, network society.

Resumen. De los años 1960 a los años 1980, un periodo "de gestión de la tensión" entre "la vieja hegemonía del catolicismo y el nacionalismo y la aparición del liberalismo y materialismo" (Fogarty 1984: 102), la autoimagen de Irlanda en tanto que comunidad moral se vio influenciada por un proceso de secularización. La secularización del país se aceleró con la adopción de nuevas tecnologías - y el consiguiente éxito económico - a principios de los años 1990, cuyos resultados para el catolicismo en Irlanda fueron la visible, y al parecer irreversible, debilitación de la institución. Mi argumento en este artículo es que, mientras que en una Irlanda que muchos veían como una nación religiosa tradicional y bien integrada, para los católicos irlandeses era posible vivir su fe de una manera institucionalizada a través de la comunidad moral idealizada y deseada tanto por la Iglesia como por el Estado, el éxito económico y la creciente internacionalización hicieron esta idea de comunidad menos sostenible. Ciertamente, en lo que ahora es una "sociedad red" (Castells 1996: 469), ha surgido una nueva generación de católicos que ya no viven su religión como una herencia trascendente, sino como una opción inmanente, y que, en consecuencia, parecen tener una "conexión" con su religión más que una “comunión” con ella.

Palabras clave. Catolicismo irlandés, comunidad moral, secularización, Tigre Celta, sociedad red.

In the ballad "Nationality", Thomas Davis, the main editor of the $19^{\text {th }}$-century Young Irish weekly The Nation, presented what he called his "crusade for nationality" as brave and fair by stating:
A nation's right, a nation's right -

God gave it, and gave, too,

A nation's sword, a nation's might,

Danger to guard it through. ${ }^{1}$

1. Quoted from John Kelly's The Spirit of the Nation (1998: 167) 
The appearance of such ballads, in The Nation, was part of the Young Irish politicocultural programme that turned O'Connell's campaign for the repeal of the 1800 Act of Union into a divine mission. ${ }^{2}$ Indeed, in The Nation's songs and poems “ (...) the fight for freedom [wa]s associated with God's will, and Irish resistance seen as a holy and righteous war against the forces of evil” (Kelly 1998: 22). The paper's nationalist rhetoric that associated nationalism with religion in general was to stimulate Ireland's nationalist movements for many years to come. Sean Oliver rightly pointed out that “ (...) without Davis's romantic ideology of the unity between heroic strife and nation, the actions of the Fenians and, in the twentieth century, the messianic nationalism of Pearse, are inconceivable" (Oliver 1993: 39). If The Nation refused religious bigotry, later nationalist movements inspired by the paper justified their nationalist struggle in the name of what they considered was Ireland's traditional faith, Catholicism. For these nationalist movements, whose cultural programme glorified a Golden Age in which everyone in Ireland was supposedly Catholic and Irish-speaking and one looked askance at progress such as that found in the United Kingdom during the Industrial Revolution, the Catholic Church, which also denounced progress, modern, liberal values, and which advocated a return to traditional Catholic societies, soon became a natural ally. This can be seen in the alliance brokered between

2. As Richard Davis underscores it in his book The Young Ireland Movement, The Nation was "established as a patriotic weekly to ginger O’Connell's Campaign", and it soon "became almost a synonym for the Young Ireland Movement, speaking in its early years for Repeal in general” (Davis: 1987, 2). O' Connell, who was known as the "Liberator" in Ireland for obtaining Catholic Emancipation in the late 1820s, had launched his Association for Repeal on $15^{\text {th }}$ April 1840. This new association claimed the repeal of the 1800 Act of Union which had turned Ireland and Great-Britain into a single Kingdom and deprived Dublin of its parliament. Even though O'Connell wanted the restoration of an independent Irish legislature, he emphasised Ireland's loyalty to the Crown and blatantly refused any breach of the law. It is in this context that The Nation, edited by a group of young intellectuals called the Young Irelanders, was launched to provide some rhetorical support to O'Connell's peaceful fight for the repeal of the Union.
Parnell and the Irish bishops in 1885. Cultural nationalists in Ireland, such as the Fenians and, later, the Celtic Revival led by the Gaelic League and Sinn Féin, tried to stop the concept of "Nation" from being associated with the stream of modernist ideas brought in in the wake of the French Revolution, so as to preserve their plan of restoring a "traditional" Irish nation that had long since passed. One could therefore believe that because most of Irish society withdrew into an inclusive form of nationalism associated with Catholicism that rejected modern values throughout the $19^{\text {th }}$ century, Ireland did not experience modernity. This would be forgetting, however, that "The history of modernity cannot simply be written in terms of increasing autonomy and democracy, but rather in terms of changing notions of the substantive foundations of selfrealization and of shifting emphasis between individualised enablements and public and collective capabilities" (Wagner 1993: 18). Thus, in their efforts to "restore" the Irish nation to the way it used to be under the banner of Catholicism, cultural nationalists in Ireland were in fact reinventing Irish traditions and Irish identity - Irish and Catholic - in the face of Anglicisation. With the growing support of the Catholic Church they were, thereby, making modern history and history modern. Throughout the $19^{\text {th }}$ century, the - at first fragile - alliance between the Catholic Church on the one hand, and nationalism and popular forces on the other hand, grew ever stronger and it eventually gave birth to a triangular structure of power - Church, State and Nation - which was to dominate most of the $20^{\text {th }}$ century. The new, modern Irish identity which was created throughout the $19^{\text {th }}$ century by Irish nationalism and, later, by the new Irish State during the early $20^{\text {th }}$ century consequently consisted of a blend of Irishness with Catholicism. Fintan O'Toole has shown how, with its symbolic occurrence at Easter and its imagery of sacrifice and redemption, the founding act of the modern Irish State, the 1916 Rising, was “(...) a religious as much as a political act, and conceived by its leader, Patrick Pearse, as such” (Kenny 1997: 60).

As soon as Ireland became a Free State, whose objectives included the reunification of the island and the restoration of the Irish language, it consequently took Catholicism as its main ideology. As Maire Nic Ghiolla Phadraig showed in her article on "The Power of the Catholic Church in the Republic of 
Ireland", even though Church and State were formally separate, the State's lack of civic ceremonial soon created a reliance on Catholic rituals with, for example, a special Mass being said for the opening of the Oireachtas each autumn. She concludes that "The [State's] willingness to concede further influence [to the Church] can be attributed to (...) a requirement for legitimation and cohesion. The Church offered the State continuity and stability and in return sought its support for continuity and stability in its own work" (Maire: 1995: 609). This alliance between Catholicism and Ireland's political project, whereby the Church gave the State the necessary legitimacy and vice versa, was even enshrined in the letter of the law, since the 1937 Constitution recognised the special position of the Catholic Church on the basis that, as de Valera himself stated in the Dáil, 93\% of the people in southern Ireland “ (...) belong to the Catholic Church" and "their whole philosophy of life is the philosophy that comes from its teachings" (Fuller 2006: 71). As a result, the new constitution, which linked Catholicism and nationalism, encouraged, to some extent, the Irish to see themselves as special, as God's chosen people. Similarly, it justified the State's efforts at constituting on a political level the Catholic practice of missions by establishing "Ireland's spiritual empire", which was thought of as a parallel of - if not a competitor to - the British Empire (Kenny 1997: 117). This anti-liberal constitution, which was secular in its genesis but intolerantly pro-Catholic, had the support of the popular forces, and it soon achieved "a synthesis between Catholic, nationalist and democratic values in a way that provided a stable basis for constitutional continuity for the next forty years" (Girvin 2002: 82).

In modern Irish society, and unlike most liberal societies, there was no clear-cut boundary between the sacred and the secular and, as a result, between political and Catholic practice. Actually, such a correlation between both practices allowed for the constitution of what Tom Inglis called, following Pierre Bourdieu's sociological theory, a Catholic "habitus" present in modern in Ireland. ${ }^{3}$ In his

\footnotetext{
3. Talking about his research, Tom Inglis explains: "To help make these connections, I rely on the work of Pierre Bourdieu. Society and everyday social life can be divided into a number of different fields. Each of these fields is characterised by a habitus which revolves around being spiritual or moral. It is this
}

study of the Church's Moral Monopoly, Tom Inglis showed how important it was, in the Catholic habitus created by modern Ireland, to be perceived as a good practising Catholic, as this gave one greater religious capital which, in turn, endowed one with greater social prestige: "In other words, being a good Catholic helped get contracts and jobs, be elected, be educated, be well-known and liked" (Inglis 1998: 11). Indeed, in this predominantly Catholic and nationalist Irish society, the leading political party, Fianna Fáil, the Catholic Church and revivalists supported the project of creating a popular, democratic community in which morality would be defined along strictly Catholic lines. Such a process gave Catholic practice a moral monopoly in Ireland which justified the Catholic Church's constant interference in Irish political life. This was exemplified by the Mother and Child Scheme, which was seen by Church authorities as an encroachment on one of their private domains, the health sector. In 1950, when the then Minister for Health Noel Browne decided to introduce a scheme which would give all mothers free maternity care and all teenagers free healthcare, regardless of income, he met with vehement resistance from said authorities and from conservative members of the medical profession. The case was rapidly blown out of proportion. Because Irish Catholic authorities considered the scheme to be against Catholic teachings (they feared it might have paved the way for birth-control and abortion), it was hastily withdrawn and Noel Browne, who had to apologise, resigned shortly afterwards. ${ }^{4}$ As John Whyte noted, up to the 1970s the reluctance of politicians to be seen as opposing the Catholic hierarchy is a clear sign that “ $(\ldots)$ there was no electoral dividend to be gained from appearing to stand up to the bishops (Whyte 1985: 4). In fact, if the Catholic

habitus which generated the habit of what it means for believers to be religious. (...). In Catholic Ireland, religious capital was not only important in attaining high positions in the religious field, but it could be used to attain other forms of capital and, thereby, high positions in other social fields" (Inglis 2003: 44).

4. See Noel Browne's autobiography Against the Tide published by Gill \& McMillan in 1986, in which the author explains how, upon entering Irish politics, he realised that the ultimate power in Ireland lay not with elected politicians but with the bishops of the Catholic church. 
Church had institutional power stemming from the 1936 Constitution and, therefore, the power to influence Irish political life, its influence largely rested on its moral power in a religious society. There was little or no anticlericalism in a modern Ireland understood as a "communing community", that is a community where everyone shared in the same ideal and ethos, that of the Catholic Church. In such a modern and "imagined" - because constructed by Irish nationalism - but traditional-looking community, lay opinion appeared to be more orthodox than the Pope himself, and religion apparently gave meaning to everyday life. That is why, according to Brian Girvin, "Catholicnationalist Ireland became democratic but it did not become liberal. Its anti-liberalism was a consequence of the Catholic Church's opposition to modernism and Irish nationalism's hostility to Britain. As a consequence, the nation's religious and political leadership could share in the rejection of the liberal version of modernity, especially in its individualism and secularism" (Girvin 2002: 18).

From the creation of the Irish State and well into the 1960s, Catholicism was therefore at its apex in Ireland, as the institutional Church turned out to be one of the great victors of the nation's war for independence. As shown by Patsy McGarry, it was a time when "Ireland was producing so many priests and nuns that between one-third and a half of them went on the missions" (2006: 32). The strength of the Catholic Church in Irish society at that time was its voluntary nature, and its success rested on the uniquely consensual nature of the moral community created after independence. Until the late 1960s, most people in Ireland accordingly "accepted the place of the Catholic Church in the community, acknowledging the superiority of the spiritual over the material." (Girvin 2002: 135). Yet just as Irish nationalism, which had achieved most of its objectives by the 1960s, had paradoxically become exhausted at that time (as shown by the decision to apply for EEC membership in 1961), its seems that the high point of its most faithful ally, the Catholic Church, had also already passed in Ireland at the end of that decade (Fahey 2005: 30). In a way, this was already exemplified by the Mother and Child Scheme. Truly, the severe defeat of the State bore witness to the supremacy of the Church in the early 1950s. Yet the scheme can also be seen as the illustration of the fact that Church teaching started to be questioned by a force now to be reckoned with in Irish society, that of civil society.

In fact, the first signs of a secular influence were felt in Ireland as early as the 1960s, a decade Mary Kenny calls the "Liberal Dawn" (1997: 240). This was probably due to the redefinition of Catholic practice and of the role of the Church in society brought about by the second Vatican Council. Started in 1962, the council, which consisted of an effort to adapt the Catholic Church to the modern world, encouraged - albeit unconsciously - the advance of secularisation. Thus, in 1965, a decree on religious freedom, Dignitatis Humanae, was promulgated, in which the Church stated that, following the increasing secular demand that “ (...) men should act on their own judgement, enjoying and making use of a responsible freedom," it recognised that "it is upon the human conscience that these obligations fall and exert their binding force. The truth cannot impose itself except by virtue of its own truth (...)." ${ }^{5}$ This decree put an end to the traditional conception of the supreme rights of truth and it put new emphasis on the rights of individuals, called "rights of the creature," in the name of human dignity. In 1971, the Church's new recognition of private judgement was reasserted with the publication of the apostolic letter Octogessima Adveniens. In this letter, the Pope clearly stressed the legitimacy of the notion of pluralism - a notion the Church had always fought until then - and justified it in the political field, a field where Christians should exert their freedom of conscience (Grootaers 1981: 106). By so doing, the Catholic Church acknowledged the world as it was, one that was ruled by cultural pluralism.

No doubt Vatican II represented a watershed in Catholic practice in Ireland and elsewhere. Whereas "the pre-Vatican II era [in Ireland] was pervaded by such concepts as 'occasion of sin' and 'impure thoughts' (...) and the sense to strive continuously for an ideal which was, in fact, unattainable" (Fuller 2002, 227), the liturgical changes contained in the new constitution on the liturgy Sacrosanctum Conciliium (1963) put far greater emphasis on the notion of salvation and on the love of God,

5. Dignitatis Humanae (§1), in: ttp://www. vatican.va/archive/hist_councils/ii_vatican_council/ documents/vat- ii_decl_19651207_dignitatishumanae_en.html 
whom Catholics should now get to know as a person. In the wake of this "religious liberation" generated by the liturgical and structural redefinition of the Catholic Church during Vatican II, a new type of Catholic consequently emerged in Ireland. These Catholics, who were a growing minority in the 1970s, were characterised by "an informed appreciation of the value of the supernatural and sacramental life of the Church, but (...) an independence of mind mainly on moral matters" (Fogarty 1984: 104). Interestingly enough, the Catholic liberalisation of the second Vatican Council coincided with what Liam Ryan calls "the creation of the second Ireland" - the one that came after de Valera's. This second Ireland, shaped by Sean Lemass and Ken Whitaker: “ (...) brought economic as well as psychological transformation to the country by providing a solid economic base" (Fogarty 1984: 101). What's more, Timothy J. Whyte more recently made the point that:

Lemass was more than an economic liberal who sought to industrialise the Irish economy at the expense of traditional nationalistic polices. Lemass and his supporters recognised that in their era only the state would be able to coordinate and promote economic development in an increasingly interdependent world economy. (...) by integrating the Irish economy with those in Europe and the rest of the world, he necessarily unleashed forces that would challenge not only the standard of living of the Irish but also their priorities and values in life. The materialistic mentality of the Irish proliferated as material conditions in Ireland dramatically improved in the 1960s. Even though Irish economic performance stagnated in the 1970s and 1980s, values and attitudes continued to change. By the 1980s the Irish had become the most materialistic nation in surveys taken of member states in the European nations (2002: 31).

The years between 1960 and 1980 in Ireland were accordingly cleverly labelled "tension management years" by Liam Ryan, who refers to the tension between the old, traditionoriented ideology of Catholicism and nationalism and the new, secular ideology of liberalism and materialism. He then went on to show that "The old order was challenged but not destroyed, it wilted but did not wither" (Fogarty 1984: 102). The early 1960s thus coincided with the creation of the first Irish television channel, RTE, in 1961 and with the advent of outward-looking national policies EEC membership application, new involve- ment in the United Nations peace-keeping process. Both were signs of the country's opening up to foreign influences. Ironically enough, about television, which was first encouraged by de Valera as a medium to further advertise his vision of a moral Ireland, Tom Inglis made the point that:

Television brought the sophisticated glossy image of urban life into the heartland of rural Ireland. It provided a constant reminder of what most Irish people were not. The demand for a modern Western lifestyle did not lag far behind the advent of television. Indeed television played a crucial role in developing and maintaining consumer demand, and this stimulated increased production. Television, then, was an important factor in the second stage of Irish modernisation which brought an end to the dominance of rural life centred on small-scale agricultural production, and its replacement by industry, urbanity and individuality, all of which added to the decline of the power of the Catholic Church (1998: 92).

Tom Inglis claims, in fact, that the media were the first to break with the tradition of not publicly questioning the Church and its teaching. This was clearly shown, in 1966, by the "Bishop and Nightie" episode of RTE's Late, Late Show in which the host, Gay Byrne, interviewed a number of couples to see how well they knew each other. Byrne asked a young woman if she could remember the colour of the nightdress she was wearing on the first night of her married life. The latter replied that she might not have worn any, which infuriated the then Bishop of Galway, who condemned the programme as filthy and immoral. Mary Kenny cleverly pointed out that “(...) intuitively, the Bishop had grasped the point that TV would challenge and eventually replace the Church as the teaching authority in manners and morals, as indeed it has also done" (1997: 267).

It was in such a context of a changing Irish society that in 1973, one year after the deletion of the clause in Article 44 of de Valera's Constitution which recognised the "special position" of the Catholic Church, the Irish hierarchy started distancing itself from its hitherto dogmatic stand during the debate over Mary Robinson's highly polemical abortion bill. In a joint statement concerning the bill, it declared: "There are many things which the Catholic Church holds to be morally wrong and no one has ever suggested, least of all the Church herself, that they should be prohibited 
by the State" (Irish Independent, 26 November 1973). Even though the bill never became law, the reaction of the hierarchy on the matter was of paramount importance, as it made clear that the State was not expected "to defend by legislation the moral teachings of the Catholic Church" (Whyte 1985: 7) and that this was a matter of private conscience for voters and politicians alike. In doing so, the Irish Catholic hierarchy was in fact simply adjusting to the new type of Catholics who were gradually becoming a majority in Ireland in the 1970s, as shown by a 1974 survey of religious practice, attitudes and beliefs. If $91 \%$ of the Irish people surveyed professed themselves to be practising Catholics and as being influenced by the value system of Catholicism, they did not, they claimed, always adhere to Church rules, particularly in the area of sexual morality (Connolly 1979: 757). Encouraged by this new attitude of the Catholic hierarchy and of the Catholic laity alike, the Fine Gael/Labour coalition led by Fitzgerald that was elected in 1981 did not hide its ambition to further enhance the liberalisation of Irish society from Catholic teachings. Soon after the election, it launched a vast "constitutional crusade" that sought to reform Ireland's institutions by making them more secular. The new Taoiseach's crusade set the tone for the whole of the 1980s and the 1990s, which were consequently decades of intense reform characterised by politicians proposing a series of laws to the Dáil and referenda to the people to make Catholic prohibitions legal in Ireland. Such as, for instance, the referenda on abortion (1983, 1992 with the infamous " $X$ " Case and 2002) and on divorce (1986 and 1995 with the victory of the "Yes" vote) which further undermined the legitimacy of the Church's influence on social and political matters. To that effect, Louise Fuller has shown how the latest referendum on abortion (2002), which ended in a victory for the "No" camp by a narrow margin, can be seen as evidence of the collapsing support of popular forces for the Catholic hierarchy in Ireland, and therefore marks "the final stage in the dismantling of legislative and constitutional support for the Catholic ethos in Ireland” (Fuller 2006: 87).

Initiated in the early 1960s, these dramatic changes undoubtedly paved the way for the economic boom of the 1990s which, in its turn, further enhanced the secularisation of Irish society. After the rather gloomy years of the economically depressed 1980s, the 1990s saw the creation of a so-called 'Celtic Tiger Ireland' characterised by sustained high levels of economic growth. Within ten years, gross domestic product (GDP) grew on average by 70 per cent each year. By the mid-1990s, an old psychological barrier was overcome when the Republic's economy overtook that of the United Kingdom for the first time in history (Considère-Charon 2002: 55). This change in the Irish economy undeniably opened up new horizons in Irish society, which gradually became more confident and outward looking. It also marked Ireland's move from defining itself as a moral community to living itself out as a materialistic and liberal secular society. In Ireland, according to Colin Coulter:

The burgeoning levels of wealth generated within the Irish Republic over the last dozen years have, of course, found increasingly stark expression in radically altered patterns of consumption. While the conceit of the Celtic Tiger connotes a great many social processes, it articulates with singular ease a particular image of how young Ireland shops, dines and plays. The accounts that appear most regularly in media portrayals of contemporary southern Irish society seek not merely to document current modes of consumption but to celebrate them (Coulter 2003: 13).

Irish society changed so much that, in the year 2000 the representation of Ireland as a rural country had definitely become a remnant of the past, as only a mere 8.5 per cent of the Irish workforce still worked in the farming industry, while 63.2 per cent of them had jobs in the service industry (Considère-Charon 2002: 62). With a now transformed economy, largely open to foreign investments and based on a thriving service industry, Ireland's sense of identity was bound to be altered by permanent contact with others, whether European (due to a continued integration into the European Union) or North American (due to the huge amount of US investments in the Irish economy). The country's increased connections with foreign - and often liberal cultural influences was also facilitated by cheaper aeroplane tickets, which made travelling abroad much more affordable for the Irish, and by the new social phenomenon of immigration. All these changes in Irish society culminated in the influential US magazine Foreign Policy voting the Republic of Ireland "the most globalised country" of the year 2001 (Coulter 2003: 110). Despite appearances, 
however, those changes did not occur overnight. Indeed, as shown by Timothy J. White in his article "Nationalism vs. Liberalism in the Irish Context: From a Postcolonial Past to a Postmodern Future":

The materialistic mentality of the Irish proliferated as material conditions in Ireland dramatically improved in the 1960s. Even though Irish economic performance stagnated in the 1970s and 1980s, values and attitudes continued to change. By the 1980s the Irish had become the most materialistic nation in surveys taken of member states in the European Union. The surge in economic growth that has occurred since 1993 as part of the Celtic Tiger phenomenon has added new momentum to social change in Ireland (2002: 31).

As a result, contemporary Ireland has turned into a real Tiger society, far from the idealised moral community wanted by nationalists, the Catholic Church and by the greater part of the population until the 1960s. Indeed, today's Ireland is much more secular and liberal in its outlook and in its attitudes, the Catholic Church having lost most (though, admittedly, not all) of its influence in the areas of education, health and social welfare during the 1980s and 1990s. It can therefore no longer be the locus of the moral community in which being Irish meant, for many, being a practising Catholic. Similarly, the Church's loss of influence on Irish society means that it has become increasingly more difficult for Irish Catholics to live out their faith in an institutionalised manner.

Nowadays, due to the Church's progressive loss of a moral monopoly, it is no longer necessary to be seen as a good practising Catholic to have social prestige, as confirmed by the general drop in Church attendance since the 1990s. In Moral Monopoly, Tom Inglis demonstrated how multifaceted the visible and apparently irreversible undermining of the Catholic institution was in contemporary Ireland. It consisted, indeed, of a decline in Catholic belief (the proportion of those of believed in God decreased from 77 per cent in 1981 to 66 per cent in 1990), in Catholic practice, in moral authority (an opinion poll from 1996 found that when it came to serious problems, 78 per cent of Catholics followed their own conscience rather than the teaching of the Church), and, finally, a decline in the institution (Inglis 1998: 204-220). According to the Irish sociologist, this decline was partly caused by the rise of the media, which soon questioned the primacy of the Catholic Church in Ireland, but also, more generally, by the culture of the time. Contemporary Irish culture is marked by an upsurge in individualism that clearly stands out in the result of the 1999 European Values Survey. In this survey, whereas $80.2 \%$ of the Irish said they felt "much or very much concerned" with their families, only $24 \%$ of them felt the same about their fellow countrymen. What is more, $88.8 \%$ of the Irish people answered that they believed that "more emphasis on individuals" would be a good thing for their country's future. This era of the ego, of hyper-individualism, contradicts, it is true, the denial of the self required to maintain a one, true and universal apostolic Church, and this is why Tom Inglis believes that: "The traditional Church soon became a fish out of water in a society saturated with media messages of self-development” (1998: 214). ${ }^{6}$ As a result, despite the long standing association between Irishness and Catholicism, less than $30 \%$ of today's population regard being Catholic as very important for being fully Irish (Fahey 2005: 69). This redefinition of Irish identity outside the alliance between nationalism and Catholicism that had made Ireland enter modernity is a clear sign that it has now abandoned it to enter, instead, a new era in which economic success and increased internationalisation have made the idea of a moral community less sustainable.

Today, the Irish are moving away from their religiously-structured view of society and their Catholic definition of the Republican ideal inspired by their Catholic habitus, according to which they conformed almost automatically to Church teaching. On the contrary, they are now working on the construction of a societal organisation free(r) from Catholic influence, as shown by the progressive secularisation of two traditional strongholds of the Catholic Church in Ireland - education and the health system. In a country where calling oneself an "Irish Catholic" has now stopped being a "badge of

6. This upsurge in individualism clearly stands out in the result of the 1999 European Values Survey. Indeed, whereas $80.2 \%$ of the Irish said they felt "much or very much concerned" with their families, only $24 \%$ of them felt the same about their fellow countrymen. What is more, in the 1999 EVS 88.8\% of the Irish answered that they believed that "more emphasis on individuals" would be a good thing for the future of their countries. 
honour" to become "an embarrassment to be reluctantly admitted", it is important for the Church to redefine its role in society. Indeed, "Modern Ireland is the nation of the Celtic Tiger rather than the land of saints and scholars (which, it could be argued, was a rather romantic notion anyway). Gone are the days when there were no weddings and dances during Lent. Vocations to priesthood and religious life are nearly non-existent" (Twomey 2003: 17-29) On the one hand, the privileged position of the Church in Ireland can no longer be taken for granted. On the other hand, the current redefinition of the Church does not mean, I believe, its disappearance.

In fact, according to Tony Fahey in Conflict and Consensus, a Study of Values and Attitudes in the Republic of Ireland and Northern Ireland: "Although Catholics in the Republic may be less assiduous in religious practice and more critical of the Catholic church than in the past, they have been slow to disavow their Catholic connections entirely" (2005: 55). This may be where our analysis of the redefinition of the Church in Ireland should start from. In the old moral community, where being a good Catholic gave one social prestige, the Irish tended to have a rather passive, legalistic vision of the Church. In such a society, the Church was therefore too strictly defined as the institution, and so it was organised along highly hierarchical lines. Yet in the 1960s the Second Vatican Council had already challenged this vision of the Church by claiming that the Church was not just about the institution, but also - and more importantly about the laity. In Celtic Tiger Ireland, this redefinition of the Church seems to have taken place, especially after the notorious sexscandals of the 1990s which represented a real breach of trust in the eyes of most Irish people. Thus, according to Brian Girvin, “A poll among Catholics in 1995 reported that 80\% believed their personal faith had not been affected by the scandals, but a majority declared that people would have less respect for the Church on moral issues. Additionally, $49 \%$ thought that the Church had too much influence in Irish life and $45 \%$ considered that it had too much influence on government (...) " (1996: 607). Nowadays, the Irish no longer expect the Catholic institution to influence Irish society and politics and, as a result, to define Irish identity for them. The general, institutional consensus about what it means to be Irish and / or Catholic has disappeared. The Irish, however, have not completely stopped "connecting" to Catholicism in their Tiger society.

On the contrary, "connecting" to Catholicism is the new way for the Irish to practice their religion in secular - that is to say pluralistic and materialistic - Ireland. In an article entitled "Catholic Church, Religious Capital and Symbolic Domination", Tom Inglis showed how the importance of religious capital used to be strongly linked to the dominance of small-scale, face-to-face communities, since: "It must be remembered that up to 1971 half the population of the Irish Republic lived in rural areas and villages with less than 1,500 people. It was, and probably still is, in these communities that religious capital had more importance (...)” (2003: 58). Nowadays, more than half the population of the Republic lives in the highly urbanised East coast around the Dublin area. This means that the Catholic Church in Ireland, understood as the sum of its members, is being redefined along urban lines. This redefinition is characterised by a general drop in Church attendance - between 1999 and 2003, the number of regular attenders and of weekly attenders fell respectively from $76 \%$ and $83 \%$ to $70 \%$ and $64 \%$ (Fahey 2005: 43) - and also by a dramatic drop in the number of people going to confession (47\% of Irish Catholics went to confession on a monthly basis in 1974, as compared to a mere $14 \%$ in 1995). This does not mean, however, that the link between Catholicism and today's Irish has been totally severed, but confirms the idea that " (...) when it comes to giving expression to their beliefs, [the Irish] increasingly prefer a private to a communal setting” (Cassidy 2002: 29). And this is shown by the fact that 60 per cent of Irish people still pray on a regular basis, which is a way for them to maintain some sort of a connection with the next world. In Ireland's secular Tiger society, Catholic identity and belief have become privatised, individualised and, therefore, plural. The sources of definition and of legitimisation of Catholic identity and belief no longer lie, as used to be the case, in the one moral community, but, on the contrary, in the plurality of individuals who can either adopt them or reject them. Thus, the definition of Catholic identity has become somewhat fragmented in an Ireland where, according to Catherine Maignant: “ (...) the disaffection of the traditional Church has led many to a spiritual quest of their own” (Maignant 2003: 
74). It is not only their identity as Irish people, but also their identity as Catholics that most Irish people do not expect the Catholic institution to continue defining for them. Irish Catholics now want a more immediate, a more authentic and a more personal link with the next world. In doing so, they are in fact becoming more like the rest of their European counterparts.

In his book about Europe and Religions. Challenges for the $21^{\text {st }}$ Century, French sociologist Jean-Marie Willaime shows that in European societies, in which the notions of liberalism and of pluralism prevail, the vertical regulation of the religious by religious institutions has gradually been replaced by a horizontal regulation since the 1960s (2004: 211-212). In the vertical regulation of the religious, religious norms were imposed on society by the institution and everyone was ascribed a role to play in the community. Such was the case in Ireland with the Catholic Church which imposed norms on society and on the State, and which gave Catholics a role to play in the moral community. In contrast, the new, horizontal regulation of the religious is characterised by the notions of choice and negotiation. Thus, today's Irish people choose their norms and negotiate the role they want to play within Irish society. This shift from a vertical to a horizontal regulation of Catholicism in Ireland was made possible, I believe, by Ireland's move from defining itself as a moral community to being a network society. According to Manuel Castells in The Rise of the Network Society:

As a historical trend, dominant functions and processes in the information age are increasingly organised around networks. Networks constitute the new social morphology of our societies, and the diffusion of networking logic substantially modifies the operations and outcomes in processes of production, experience of power and culture (1996: 469).

In Celtic Tiger Ireland, in which the paradigm of information technologies provides the social structure with the necessary material means to expand, networks definitely constitute the new social morphology of society. And in the now horizontal, networkbased regulation of Irish society, the Irish no longer agree to belong to one institution imposing its norms in an arbitrary fashion. The Irish in general - and Irish Catholics in particular - now connect, more or less intensely and following extremely variable modes, to relational networks that potentially match their needs and expectations.

This crisis of the typically modern notion of "belonging" in Irish society is part of the more general process of desinstitutionalisation that is so characteristic of postmodern societies. In Ireland, members of the Catholic Church have consequently stopped being members of a "communing community", in which consensus prevailed and which was part of, if not synonymous with, the greater moral community that Ireland was held to be at the time, to become instead members of a "connecting community", which is itself part of the greater network society that Celtic Tiger Ireland has become. In this redefined Catholic community, punctual participation in the life of the community is preferred to staunch belonging, as shown by the increase in the number of irregular church attenders from $24 \%$ in 1999 to 30\% in 2003 (Fahey 2005: 43). It is therefore clear that Catholic identity and Catholic practices are currently being redefined in Ireland so as to be adjusted to the new way of belonging to a community at a time of hyper-individualism. In a now secularised and pluralist Ireland, it has become impossible to live one's Catholic identity as exclusively as used to be the case. In a way, it is not only Irish society but Irish Catholicism as a whole that has been secularised. Catholic belief in Ireland is not so much in crisis as in the process of redefinition. Ireland's self-image as a moral community came under the influence of secularisation and Irish Catholics now have to acknowledge that the message they believe in is not the only valid one. The secular redefinition of Catholic belief in Ireland is one that has taken place outside of the institution, at the level of the individual, in a multitude of networks that enable the new type of Catholics to belong through punctual connections instead of a blind communion, and therefore to belong to the Catholic community while maintaining a postmodern sense of independence from its institution. It has therefore become impossible to give a unique sociological definition of what it is to be an Irish Catholic, as this sense of identity has been reappropriated by Irish individuals and has consequently become much more diffuse. This is why I hope that this article will have made clear that, if it is only fair that contemporary sociological studies of Irish society should focus on the plurality of 
religious outlooks that need to be given a say in Irish society, they should also concentrate on the redefinition of Catholic identity - and not just on its crisis - just as they should consider the myriad Catholic outlooks on what it is to be Irish and Catholic that still have to be expressed.

\section{Work Cited:}

Cassidy, Eoin (ed.). 2002. Measuring Ireland. Discerning Values and Beliefs. Dublin: Veritas.

Castells, Manuel. 1996. The Rise of the Network Society. London: Blackwell.

Connolly, Peter. 1979. “The Church in Ireland Since Vatican II”, The Furrow, 30:12.

Considère-Charon, Marie-Pierre. 2002. Irlande, une singulière intégration européenne. Paris: Economica.

Coulter, Colin and Coleman, Steve. 2003. The End of Irish History? Critical Reflection on the Celtic Tiger. Manchester: Manchester UP.

Davis, Richard. 1987. The Young Ireland Movement. Dublin: Gill \& Macmillan.

Fahey, Tony, Hayes, Bernadette and Sinnott, Richard. 2005. Conflict and Consensus. A Study of Values and Attitudes in the Republic of Ireland and Northern Ireland. Dublin: Institute of Public Administration.

Fogarty, M., Ryan, L. and Lee, J. 1984. Irish Values and Attitudes. Dublin: Dominican Publications.

Fuller, Louise. 2002. Irish Catholicism Since 1950: the Undoing of a Culture. Dublin: Gill \& Macmillan.

Fuller, Louise. 2006. "New Ireland and the Undoing of the Catholic Legacy: Looking Back to the Future" in Littleton, John and Maher, Eamon (eds.). Irish and Catholic? Towards an Understanding of Identity. Dublin: The Columba Press, pp. 68-89.

Girvin, Brian. 2002. From Union to Union. Nationalism, Democracy and Religion in Ireland - Act of Union to EU. Dublin: Gill \& Macmillan.

. 1996. "Church, Sate and the Irish Constitution: The Secularisation of Irish Politics?” in Parliamentary Affairs, 49:4, pp. 599-615.

Grootaers, Jan. 1981. De Vatican II à Jean-Paul II: le grand tournant de l'Eglise catholique. Paris: Editions du Centurion.

Inglis, Tom. 1998. Moral Monopoly. The Rise and Fall of the Catholic Church in Modern Ireland. Dublin: UCD Press.

Inglis, Tom. 2003. “Catholic Church, Religious Capital and Symbolic Domination” in Böss, Michael and Maher, Eamon (eds.). 2003. Engaging Modernity. Readings of Irish Politics, Culture and Literature at the Turn of the Century. Dublin: Veritas, pp. 43-65.

Kelly, John . 1998. The Spirit of the Nation by Ch. G. Duffy and others. Hibernia - Woodstock Books: Washington D.C.

Kenny, Mary. 1997. Goodbye to Catholic Ireland. London: Sinclair-Stevenson.

McGarry, Patsy. 2006. “The Rise and Fall of Catholicism in Ireland” in Fuller, Louise, Littleton, John and Maher, Eamon (eds.). Irish and Catholic? Towards an Understanding of Identity. Dulin: The Columba Press, pp. 31-46.

Maignant, Catherine. 2003. "Re-imagining Transcendence in the Global Village” in Böss, Michael and Maher, Eamon (eds.). Engaging Modernity. Readings of Irish Politics, Culture and Literature at the Turn of the Century. Dublin: Veritas, pp. 71-84.

Maire Nic Ghiolla Phadraig. 1995. "The Power of the Catholic Church in the Republic of Ireland” in Clancy, P., Drudy, S., Lynch, K. and O’Dowds, L. (eds.). Irish Society: Sociological Perspectives. Dublin: Institute of Public Administration, pp. 593-619.

Oliver, Sean. 1993. “Irish Revolutionary Nationalism: Tone to Pearse” in O’ Connell , Maurice (ed.) . People Power, Proceedings of the $3^{\text {rd }}$ Annual Daniel O'Connell Workshop. D.O.C.A.L .

Twomey, Vincent. 2003. The End of Irish Catholicism? Dublin: Veritas. 
Wagner, Peter. 1993. A Sociology of Modernity: Liberty and Discipline. London: Routledge.

White, Timothy, J. 2002. "Nationalism VS. Liberalism in the Irish Context: From a Postcolonial Past to a Postmodern Future” in Eire-Ireland, An Interdisciplinary Journal of Irish Studies, 38:3 \& 4, pp 25-37.

Whyte, James H. 1985. "Recent Developments in Church-State relations" in Journal of the Department of the Public Services, 6:3, pp. 4-10.

Willaime, Jean-Marie. 2004. Europe et religions. Les enjeux du XXIe siècle. Paris: Fayard. 